\title{
Eksistensi dan Gaya Kepemimpinan Radio Lokal
}

\author{
Anna Puji Lestari dan Sunarto \\ Program Studi Magister Ilmu Komunikasi UNDIP Semarang \\ Email: annapujilestari@gmail.com \\ Email: sunartoo@yahoo.com
}

\begin{abstract}
This research is about existence and style of local radio leadership in Semarang. The purpose of this research is to describe the existence and style of leadership one of the local radio in Semarang. The radio which was chosen in this research is Idola FM which has radioidola.com site. This research type is descriptive with qualitative approach in constructivist paradigm with phenomenology research design. The subject of primary research is the editor of Idola FM. Primary data was from in-depth interview with informant. The results stated that the rapid development of communication and information technology enlarged the capacity of the radio media industry. This is of course supported by a qualified leadership. Idola FM strengthens its existence because applies media convergence (integration of online and on air broadcast) as well as presenting positive journalism news that does not damage the listener psycological. In relation to support the existence of Idola FM, the leadership style adopted by the Chief Editor is to encourage community spirit. That is, leaders recognize the contribution of its members through awards for achievements that have been achieved.
\end{abstract}

Keywords: Leadership, Idola FM, Semarang

\begin{abstract}
Abstrak
Penelitian ini mengkaji eksistensi dan gaya kepemimpinan radio lokal di Semarang. Tujuan dari penelitian ini adalah mendeskripsikan eksistensi dan gaya kepeimpinan salah satu radio lokal di Semarang. Radio yang dipilih dalam penelitian ini adalah Idola FM yang memiliki situs radioidola. com. Tipe penelitian ini bersifat deksriptif dengan pendekatan kualitatif dalam paradigma konstruktivis dengan desain penelitian fenomenologi. Subyek penelitian primer adalah pemimpin redaksi Idola FM. Data primer berupa hasil wawancara mendalam dengan informan penelitian. Hasil penelitian menyatakan, Idola FM semakin meneguhkan eksistensinya karena menerapkan konvergensi media (integrasi siaran online dan on air) serta menghadirkan berita jurnalisme positif yang tidak merusak psikologis pendengar. Untuk mendukung eksistensi Idola FM, gaya kepemimpinan yang dianut Pemimpin Redaksi adalah mendorong semangat komunitas. Artinya, pemimpin mengakui kontribusi para anggotanya melalui penghargaan atas prestasi yang sudah dicapai.
\end{abstract}

Kata Kunci: Kepemimpinan, Idola FM, Semarang. 


\section{Pendahuluan}

Keberadaan internet telah membuat sistem pernyebaran informasi dari satu sumber ke banyak orang (one to many) beralih menjadi informasi dari banyak sumber ke banyak orang (many to many). Informasi many to many mensyaratkan interaktivitas antara produsen dan konsumen berita di media massa. Salah satu media massa yang eksis hingga sekarang adalah radio. Sebagai sebuah industri, perusahaan radio tentu harus menyesuaikan diri dalam persaingan bisnis media di era global seperti sekarang ini. Di era global, pentingnya peranan internet semakin diperhitungkan. Pandangan yang menyatakan bahwa internet merupakan ancaman bagi media massa cetak dan elektronik ternyata salah. Nyatanya, kemampuan suatu perusahaan media memanfaatkan peluang industri dari kemajuan internet justru bisa memperkuat sebarannya. Perjumpaanberitadenganinternetmerupakantipe baru jurnalisme karena memiliki sejumlah fitur dan karakteristik yang berbeda dari jurnalisme tradisional, yakni fitur-fitur yang mengemuka dalam teknologi. Internet mampu menawarkan kemungkinan-kemungkinan tidak terbatas dalam memproses dan menyebarkan berita. Pavlik (2001) menyebut tipe baru jurnalisme ini sebagai "contextualized journalism," karena mengintegrasikan tiga fitur komunikasi yang unik: kemampuan-kemampuan multimedia berdasarakan platform digital, kualitaskualitas interaktif komunikasi online, dan fiturfitur yang ditatanya (customizable features). Rafaeli dan Newhagen mengidentifikasi lima perbedaan utama yang ada di antara junralisme online dan media massa tradisional (elektronik, cetak), yakni: (1) Kemampuan internet untuk mengkombinasikan sejumlah media, (2) Kurangnya tirani penulis atas pembaca, (3) Tidak seorang pun dapat mengendalikan perhatian khalayak, Internet dapat membuat proses komunikasi berlangsung sinambung, dan (5) Interaktivitas web (dalam Deuze, 2001: 6). Dengan demikian, jurnalisme online merupakan jurnalisme yang berubah. Perubahan-perubahan yang dibawa oleh kemungkinan-kemungkinan teknologi mengartikulasikan kembali peranan-peranan dan fungsi-fungsi jurnalistik. Fungsi dan peranan jurnalistik juga hadir dalam siaran radio berita. Arti penting keberadaan radio diatur dalam UU Peyiaran Nomor 32 Tahun 2002. Pada Pasal 1 Ayat 3 Undang-Undang disebutkan, "Penyiaran radio adalah media komunikasi massa dengar, yang menyalurkan gagasan dan informasi dalam bentuk suara secara umum dan terbuka, berupa program yang teratur dan berkesinambungan." Secara khusus, sistem perijian frekuensi radio diatur dalam Pasal 17 Ayat 1,2,4,5, dan 6 . Kemudian, karakteristik atau ciri khas radio disebutkan pada pasal tersebut Ayat 3 yang berbunyi, "Format stasiun adalah ciri atau karakteristik suatu stasiun penyiaran radio berdasarkan bagian dominan dari isi siaran secara keseluruhan yang penetapannya dikaitkan dengan kebutuhan dan keinginan khalayak sasaran yang akan dijangkau oleh stasiun tersebut. Penerapan yang menyangkut format stasiun radio diberlakukan secara bertahap sesuai dengan hasil penelitian dan kebutuhan." Dengan demikian, adanya unsur khalayak sasaran yang akan dijangkau oleh stasiun radio, membuat radio menjaga lokalitas sehingga memiliki ciri khas yang membedakannya dari media lain. Di Jawa Tengah, kota Semarang memiliki stasiun radio terbanyak. Kota Kudus memiliki 10 stasiun radio, Jepara, 6 stasiun radio, Demak 2 stasiun radio, Surakarta 29 stasiun radio, Pati 3 stasiun radio. Artinya, radio di Semarang mampu menjaga eksistensi dan lokalitasnya. Eksistesi dan lokalitas perusahaan radio semakin didukung sebarannya dengan kehadiran internet. Internet memungkinkan terciptanya sistem media yang mampu mengeliminasi batasan ruang dan waktu. Hal tersebut memungkinkan informasi mampu ditransformasikan kepada khalayak secara cepat dan efektif, sebagaimana yang dilakukan salah satu radio berita besar di Semarang, Idola FM. Idola FM berbeda dari radio berita lain di Semarang. Radio ini memiliki prinsip 'Bad News is Not a Good News.' Tentu saja, ini 
menarik diteliti karena pada umumnya siaran radio memegang falsafah sebaliknya. Selain itu, falsafah yang dianut radio tersebut kemudian membawa pemasukan iklan yang tidak sedikit dan jumlah pendengar yang banyak untuk ukuran radio lokal di Jawa Tengah. Sebagai radio berita, jumlah pendengar Idola FM mencapai 100 ribu berdasarkan survei AC Nielsen dengan pemasukan iklan mencapai 200 Juta sebulan. Rata-rata, radio lokal lain di Semarang belum bisa mencapai jumlah tersebut. Ditambah, jumlah total SDM di Idola FM mencapai 50 orang, sedangkan radio lokal lain cukup dengan 10 orang saja. Idola FM telah 14 tahun berdiri. Sebelumnya, radio tersebut memiliki format dangdut. Radio dangdut ditinggal pasar dan memiliki peluang iklan sedikit sehingga mulai tahun 2004, Idola FM berubah menjadi radio berita.

Stasiun radio di Indonesia jumlahnya cukup banyak. Tentu memiliki pengaruh besar pada kehidupan sosial, ekonomi, dan politik di masyarakat. Faizal Noor menyatakan, perkembangan teknologi komunikasi dan informasi yang cukup pesat menunjukkan makin besarnya kapasitas infrastruktur komunikasi, sehingga akan memperbesar kapasitas industri media (2015: 284). Dari sisi ekonomi, radio tidak hanya sebagai sumber informasi tetapi juga dapat menjadi sumber motivasi masyarakat untuk mencari kehidupan yang lebih baik sesuai dengan perkembangan situasi yang dapat didengar dari radio. Bisa dikatakan, kontribusi media radio pada perkembangan ekonomi nasional cukup besar (Faizal Noor, 2015: 311). Karenanya, penelitian menganai eksistensi dan gaya kepemimpinan radio penting untuk dilakukan. Penelitian ini mengangkat tema mengenai kepemimpinan radio lokal di Semarang yang semakin eksis di era internet saat ini. Eksistensi perusahaan media tentu saja tak bisa lepas dari gaya kepemimpinan yang dianut. Dalam sebuah industri berita, tugas kepemimpinan di redaksi media memegang peranan penting. Kepemimpinan redaksi diarahkan untuk mengembangkan kemajuan industri media yang dikelolanya. Pemimpin dalam industri media dituntut fokus pada tujuan organisasi serta mampu melakukan adaptasi dengan perkembangan ekonomi bisnis saat ini. Dalam realitanya, tidak semua pemimpin mampu melakukan adaptasi. Akibatnya, media yang dikelola terancam gulung tikar atau mengalami kebangrutan karena tidak mampu mempertahankan eksistensinya. Terkait hal itu, penelitian ini ingin menjawab pertanyaan, bagaimana sesungguhnya eksistensi dan gaya kepemimpinan di ruang redaksi Idola FM? Tujuan penelitian ini adalah mendeskripsikan eksistensi dan gaya kepemimpinan Idola FM. Penelitian ini menggunakan paradigma konstruktivis. Pada penelitian semacam ini, tidak dikenal kebenaran tunggal atau mutlak (Guba dan Lincoln, 2011). Artinya, kebenaran ada pada siapa pun. Guba dan Lincoln menyatakan, sifat pengetahuan dari paradigma ini adalah mempertemukan antara makna kultural dan makna interpretasi seseorang. Penelitian ini ada pada paradigma konstruktivis karena bertujuan menangkap pengalaman kepemimpinan redaksi Idola FM dalam mengadaptasi gaya jurnalisme sesuai perkembangan jaman saat ini dan berpengaruh pada eksistensinya.

Dalam kaitannya dengan radio, terdapat beberapa penelitian tedahulu. Penelitian yang dilakukan Atika, Lubis dan Rangkuti (2017) berjudul "Tingkat Pemenuhan Informasi Petani Melalui Radio Komunitas" mengungkap tingkat pemenuhan kebutuhan informasi petani melalui radio komunitas. Hasil penelitian tersebut menyatakan, frekuensi dan durasi mendengarkan radio merupakan faktor yang berhubungan dengan tingkat pemenuhan kebutuhan informasi melalui radio komunitas.

Penelitian yang dilakukan Nur Ahmad (2015) berjudul "Radio Sebagai Sarana Media Massa Elektronik." Hasil penelitian tersebut menyatakan bahwa radio memiliki keunggulan karena efisiensi waktu, mampu menghasilkan informasi dalam waktu yang singkat. Penelitian yang dilakukan Ida Bagus 
Widiana, A.A. Gede Agung, I Kadek Suartama (2015) berjudul "Pengembangan Program Siaran Radio Melalui Acara Kreativitas Sastra Programa 2 RRI Singaraja Pada Siswa Pengambil Ekstrakulikuler Jurnalistik di SMP Negeri 2 Singaraja Tahun Ajaran 2014/2015." Hasil penelitian tersebut menyatakan, program siaran radio efektif untuk meningkatkan kemampuan ekstrakulikuler sastra dan jurnalistik pada siswa pengambil ekstrakulikuler sastra dan jurnalistik di SMP Negeri 2 Singaraja.

Penelitian yang dilakukan Aydin Azizi, Ali Vatankhah Barenji, Majid Hashmipour (2016) berjudul “Optimizing Radio Frequency Identification Network Planning Through Ring Probabilistic Logic Neurons." Hasil penelitian menyatakan Algoritma Ring Probabilistic Logic Neuron merupakan soulsi utama untuk masalah perencanaan jaringan identifikasi frekuensi radio bila dibandingkan dengan algoritma genetika dan optimasi partikel swarm.

Penelitian yang dilakukan JingWang dan Miodrag Bolic (2017) berjudul "Indoor Localization Using Augmented Ultra-highfrequency Radio Frequency Identification System for Internet of Things." Hasil penelitian menyatakan, model probabilitas pendeteksian yang baru dan lebih realistis bisa mengatasi hambatan-hambatan teknis yang ada.

Berdasarkan paparan penelitian terdahulu, terlihat bahwa penelitian mengenai kepemimpinan radio belum pernah dilakukan sama sekali. Artinya, penelitian yang dilakukan saat ini mengandung kebaruan dan memiliki implikasi praktis bagi penerapan gaya kepemimpinan perusahaan media massa.

Penelitian ini menggunakan pendekatan fenomenologi untuk memahami eksistensi dan gaya kepemimpinan pada proses keredaksian di Idola FM. Anderson menyatakan, pendekatan fenomenologi menitikberatkan pada pengalaman sadar seseorang (dalam Littlejohn dan Foss, 2008: 38). Tradisi fenomenologi berasumsi bahwa seseorang secara aktif menginterpretasi pengalaman mereka dan memahami dunia dengan pengalaman pribadinya (Littlejohn dan Foss,
2008: 38).

Penelitian ini mengacu pada pendekatan Fenomenologi Husserl. Fenomenogi Husserl (dalam Sobur, 2013: 30) membongkar ide dengan cara mereduksi fenomenologi dunia spatiotemporal. Reduksi fenomenologi dunia spatiotemporal adalah pemurnian fenomena, baik fenomena dunia objek maupun dunia subjek, dari segala jenis prasangka, asumsi, penafsiran, dan lain-lain. Hasil dari reduksi spatio-temporal adalah kesadaran murni, yakni suatu arus penerima pengalaman yang tak terpalsukan secara terus-menerus. Menurut Husserl, setiap kesadaran berarti menyadari tentang sesuatu, consciousness of something. Husserl menyatakan, fenomena pengalaman adalah apa yang dihasilkan oleh kegiatan dan susunan kesadaran kita.

Penelitian ini mengacu pada pengalaman sadar seorang pemimpin redaksi akan gaya kepemimpinannya guna mendukung eksistensi media massa yang dikelolanya. Kepemimpinan menurut Stephen P. Robbins adalah kemampuan untuk mempengaruhi suatu kelompok ke arah tercapainya tujuan (2003: 40).

Kesadaran diri pemimpin misalnya, bisa menerapkan adagium "seorang pemimpin yang baik adalah pemimpin yang paling sedikit memimpin, tapi seorang pemimpin yang yang tidak baik adalah pemimpin yang terlalu banyak memimpin." Artinya, jika seorang pemimpin terlalu banyak mengurusi berbagai urusan, setiap keputusan akan selalu tergantung pada diri pemimpin tersebut. Akibatnya, setiap karwayan tidak pernah bisa berinisiatif dalam mengambil keputusan karena takut keputusan yang diambil salah di mata pimpinan. Kondisi seperti itu menyebabkan setiap terdapat masalah selalu harus ditanyakan kepada pemimpin. Untuk menghindari hal tersebut, seorang pemimpin setidaknya bisa memenuhi hukum-hukum kepemimpinan.

Hukum-hukum kepemimpinan adalah (Sudarmadi dalam Fahmi, 2014: 184): (1) Adanya sinkronisasi antara tujuan organisasi dengan tujuan pribadi para anggota organisasi yang bersangkutan; (2) Suasana dan iklim kerja yang menyenangkan dan penuh persahabatan; (3) In- 
formalitas yang dipadu secara baik dengan formalitas dalam interaksi antara pimpinan dan bawahan; (4) Tidak memperlakukan manusia sama dengan mesin; (5) Pengembangan kemampuan bawahan sampai ke tingkat yang maksimal; (6) Pekerjaan yang menarik dan penuh tantangan, bukan bersifat rutin; (7) Pengakuan dan penghargaan atas pelaksanaan tugas dengan baik; (8) Sarana dan prasarana kerja yang memadai; (9) Penempatan yang tepat berdasarkan keahlian, keterampilan dan pengalaman seseorang; (10) Balas jasa yang setimpal dengan jasa yang diberikan sehingga menjamin taraf hidup yang wajar. Untuk menjalankan hukum-hukum tersebut, dibutuhkan kekuasaan dari seorang pemimpin.

Kekuasaan pemimpin terdiri dari lima jenis yakni, (1) Kekuasaan sah (legitimasi) yang diperoleh melaui hierarkhi organisasi; (2) Kekuasaan balas jasa misalnya promosi, peningkatan gaji; (3) Kekuasaan paksaan (coercive) yakni mengggunakan ancaman psikologis, emosional, atau fisik; (4) Kekuasaan referen yang didasarkan pada kesetiaan atau kharisma; (5) Kekuasaan ahli diperoleh karena memiliki keahlian (Ricky W. Griffin, 2003: 70).

Sedangkan pemimpin sendiri tentu saja memiliki bermacam tipe. Tipe-tipe pemimpin menurut S. P. Siagian (dalam Alma, 2009: 18) adalah: (1) Tipe otokratisasi atau diktatoral; (2) Tipe militeristis; (3) Tipe partenalistis; (4) Tipe laissez faire; (5) Tipe Demokratis atau partisipatif. Tipe-tipe tersebut kemudian membawa seorang pemimpin pada ciri khas atau ciri khusus yang hanya dimilikinya dan belum tentu dimiliki pemimpin lain. George R. Terry (dalam Brantas, 2009: 159) mengemukakan delapan ciri pemimpin, yaitu: energi, stabilitas emosi, human relationship, personal motivation, communication skill, teaching skill, social skill, technical cempetent.

Dalam industri media, menurut Herrick kepemimpinan bisa dilakukan dengan menggunakan model panutan, menginspirasi untuk menghayati visi, menantang proses, mendorong orang lain bertindak, dan mendorong semangat komunitas (2003: 107-121). Model panutan dila- kukan dengan menyelaraskan nilai-nilai personal dan ucapan serta tindakan dalam kehidupan sehari-hari organisasi. Pemimpin, tentu saja harus bisa memberi teladan dengan bersikap konsisten antara ucapan dan tindakan. Menginspirasi untuk mengayati visi dilakukan seorang pemimpin dengan cara mengkondisikan masa depan melalui imajinasi yang menarik dan kemungkinankemungkinan untuk meraih masa depan tersebut dengan mengajak orang lain untuk menghayati dan masuk di dalamnya. Menantang proses adalah pemimpin yang mencari peluang melalui cara-cara inovatif untuk perubahan, pertumbuhan dan kemajuan. Mendorong orang lain bertindak adalah model pemimpin yang menciptakan kolaborasi melalui dorongan guna mencapai tujuan bersama-sama dan membangun kepercayaan di kalangan anggota organisasi. Mendorong semangat komunitas adalah pemimpin mengakui kontribusi para anggotanya melalui penghargaan atas prestasi yang sudah tercapai.

Menurut Sylvie, Wicks, Hollified, Lacy dan Sohn (dalam Sunarto, 2016: 11), kepemimpinan dalam manajemen media membutuhkan keahlian komunikasi dan mendengarkan, pemberdayaan, pelatihan, pendelegasian, ketegasan, keteguhan, pemecahan masalah, penentuan tujuan, pengelolaan konflik, dan negosiasi.

Kepemimpinan suatu industri media yang tepat akan membawa perusahaan media maju di tengah persaingan industri media yang ketat. Dalam kerja dunia radio, penerapan manajemen siaran secara profesional akan menghasilkan output siaran yang berkualitas, baik dan benar, sebagai hasil kerja kolektif (kerja tim).

\section{Metode Penelitian}

Tipe penelitian ini bersifat deksriptif dengan pendekatan kualitatif dalam paradigma interpretif dengan desain penelitian fenomenologi. Penelitian ini dilakukan di Idola FM yang memiliki situs radioidola.com.

Subyek penelitian primer adalah pemimpin redaksi Idola FM. Alasan dipilihnya pemimpin redaksi sebagai informan dikarenakan redaksi merupakan ujung tombak bagi industri radio 
berita. Dataprimer diperoleh darihasil wawancara mendalam dengan informan penelitian. Data sekunder diperoleh dari data lain yang relevan dalam penelitian yang diperoleh melalui studi kepustakaan dan wawancara tidak terstruktur. Analisis data menggunakan prosedur analisis fenomenologi transendetal yang meliputi kegiatan: (1) Proses epoh, (2) Reduksi fenomenologi transendetal, (3) Variasi imajinasi, dan (4) Sintesis makna dan esensi melalui analisis gabungan deskripsi tekstural dan gabungan deskripsi struktural (Husserl dalam Moustakas, 1994: 85-100). Tahap pertama adalah proses epoh. Proses epoh yaitumeniadakan pemikiran bias mengenaisegala sesuatu. Artinya, kita mencegah munculnya segala hal mengenai referensi yang kita miliki sebelumnya dan menerima pengalaman baru. Tahap kedua, reduksi fenomenologi adalah mendeskripsikan bahasa-bahasa tekstual seseorang (informan), tidak hanya sebagai objek eksternal, tetapi juga kesadaran perilaku internal. Tahap ketiga, variasi imajinasi, adalah mencari kemungkinan makna melalui imajinasi dalam kerangka referensi, meletakkan sikap yang berlawanan dan merupakan pembalikan, dan mendekati fenomena dari perspektif berbeda. Tahap keempat, merupakan proses yang terakhir adalah sintesis makna dan esensi melalui analisis gabungan deskripsi tekstural dan gabungan deskripsi struktural. Langkah ini memandu menegakkan esensi pengetahuan (Husserl dalam Moustakas, 1994: 100).

\section{Hasil dan Pembahasan}

Temuan penelitian ini terbagi menjadi dua tema: eksistensi dan gaya kepemimpinan Idola FM. Idola FM dapat eksis karena didukung oleh gaya kepemimpinan yang relevan dengan persaingan media massa yang dibutuhkan saat ini. Berikut pemaparannya:

\section{Eksistensi Idola FM}

Idola FM menganut jurnalisme konvergensi karena menggabungkan jurnalisme dari berbagai bentuk, meliputi audio, foto, dan video, ke dalam satu bagian atau kelompok yang mewujud pada portal radioidola.com. Portal radioidola.com dibuat untuk dua hal: Pertama, sebagai bagian dari konvergensi media dan menyesuaikan dengan munculnya era New Media (Media Baru) yang ditandai dengan media berbasis jaringan internet atau dalam jaringan (daring). Sehingga, dalam konten radioidola.com, disajikan media dalam multi platform: streaming, berita online, audio, dan video (audio visual). Meskipun sejauh ini proporsi berita online lebih besar ketimbang audio dan video di situs tersebut, karena keterbatasan SDM di internal Idola FM. Kedua, portal radioidola.com merupakan salah satu strategi bisnis perusahaan. Sebab, melalui radioidola.com, pemasang iklan tidak hanya bisa mengiklankan produknya secara audio, tetapi juga secara visual kepada khalayak atau masyarakat yang mengakses internet. Radioidola.com unggul melalui live streaming. Live Streaming bertujuan agar jangkauan coverage area lebih luas tak terbatas, tidak hanya mengandalkan daya jangkau stasiun pemancar yang terbatas. Selain itu, saat ini merupakan era semua dalam jaringan dan jaman dunia dalam genggaman, sehingga konsumen berita Idola FM melalui streaming tetap bisa melakukan akses di mana pun berada asalkan memiliki koneksi internet. Newsroom radioidola.com mengusung jurnalisme positif "Good News is Good News and Bad News is Bad News" dan spirit Jurnalisme Memandu dan Membantu yang relevan dengan kepentingan publik. Terdapat perbedaan antara Idola FMdan radioidola.com. Idola FM outputnya adalah siaran on air, sementara radioidola.com outputnya berupa materi berita ber-platform online. Tentu saja, kedua hal tersebut membuat cara dan teknik penyajian juga berbeda. Pun, dalam proses produksi dan penyajiannya. Radioidola.com memiliki satu tim khusus di bagian perancang multimedia, website dan media sosial. Portal radioidola.com berfungsi untuk mengunggah materi dalam website dan menyebarkan pada media sosial yang dimiliki Idola FM misalnya ke twitter, fanpage Facebook 
dan Instagram. Namun, tidak semua materi di Idola FM juga dimasukkan dalam radioidola.com. Eksistensi Idola FM terkait erat dengan falsafah jurnalisme positif. Salah satu berita berjudul "Radikalisme Ancam Hak-Hak Perempuan" ditulis oleh Heri Candra S. yang diunggah di radioidola.com pada 23/5/2017 bisa dikatakan merupakan wujud jurnalisme positif. Sebagaimana wujud konvergensi media, materi tersebut kemudian didiskusikan secara interaktif dalam program Good to Great mulai pukul 06.0009.00 WIB di Idola FM. Diskusi berlangsung pada satu jam antara pukul 07.00-08.00 WIB. Sisi positif yang ingin dibangun dari berita tersebut sesuai tujuan penulisan berita, yakni menjadi sebuah ruang civil society untuk mencermati isu aktual yang sedang mengemuka. Tema pemberitaan "Radikalisme Ancam HakHak Perempuan" dipilih Idola FM karena isu radikalisme sudah sedemikian masif menyasar warga Indonesia. Salah satu pihak yang menjadi korban adalah kalangan perempuan. Tujuan positif penulisan berita tersebut, agar publik lebih aware pada isu semacam ini dan tentunya mampu meresponsnya agar tidak berdampak buruk. Melalui berita ini, Idola FM hendak mengingatkan kepada warga, sekaligus memperingatkan pemerintah agar hadir pada persoalan serius ini. Sebab, jika tak disikapi dan diantisipasi, akan berdampak jangka panjang pada generasi muda mendatang. Untuk menjaga eksistensinya, di samping menjalankan konvergensi media, Idola FM teguh pada kode etik dari asosiasi wartawan dan mempertahankan In-house Ombudsman. In-house Ombudsman ditugaskan untuk mengawasi agar semua wartawan dalam pelaksanaan fungsi jurnalistikya tetap menegakkan peraturan, termasuk standar etika perusahaan media dalam menjalankan tanggung jawab kerjanya kepada publik. Eksistensi Idola FM semakin kuat karena menerapkan jurnalisme konvergensi. Jurnalisme konvergensi merupakan jurnalisme yang muncul darigabungan berbagai bentuk jurnalisme, seperti cetak/audio, foto, dan video, ke dalam satu bagian atau kelompok (Liliweri, 2011: 926). Jurnalisme konvergensi Idola FM yang diperantarai internet terbukti mampu mempertahankan eksistensi perusahaannya karena memperluas sebarannya. Kemampuan suatu perusahaan media memanfaatkan peluang industri dari kemajuan internet justru bisa mempeluas sebarannya. Internet memungkinkan terciptanya sistem media yang mampu mengeliminasi batasan ruang dan waktu. Hal itu memungkinkan informasi mampu ditransformasikan kepada khalayak secara cepat dan efektif. Sebagaimana ditegaskan Steve Ross, bisnis media harus tetap berhubungan dengan internet karena merupakan jiwa news gathering (dalam Quinn dan Lamble, 2012: 3). Idola FM tetap berhubungan dengan internet melalui radioidola.com, oleh Green dan Jenkins hal tersebut dinyatakan sebagai wujud dari sebaran media. Sebaran media adalah proses dimana suatu konten yang dipilih dapat menyebar ke orang lain dengan jarak jauh dan jumlah yang banyak dan tak terbatas (Green dan Jenkins dalam Nightingale, 2011: 120). Sebaran siaran Idola FM semakin luas karena siarannya kapan pun bisa diakses melalui internet dengan perangkat komputer maupun ponsel. Keberadaan ponsel sebagai media komunikasi, menurut Gerard Goggin merupakan kehadiran yang tidak tampak dalam masyarakat dan budaya. Melalui ponsel, peran komunikasi menjadi sentral dan tidak dapat dihindari (2006: 2). Selain itu, untuk mempertahankan eksistensinya, berita yang disajikan Idola FM mengedepankan konsep berita positif. Berita positif memiliki manfaat menciptakan hubungan baik dengan berbagai pihak, sebagaimana hasil penelitian yang dilakukan Nugrahaning Esa Pratiwi dan kawan-kawan tahun 2015. Wujud berita positif yang dikembangkan Idola FM adalah dengan menganut falsafah "bad news is not a good news." Falsafah demikian diterapkan dengan menganut pertimbangan, apakah berita memiliki relevansi bagi pendengar? Apakah permasalahan di masyarakat yang ada? Apakah perhatian Idola FM yang diberikan untuk kebaikan publik? Apakah pendengar akan 
peduli? Hal-hal tersebut jika merujuk pada pernyataan Valerie Geller, merupakan unsur radio poweful (2007: 2). Dengan demikian, bisa dikatakan Idola FM merupakan radio powerful karena memiliki unsur-unsur tersebut.

\section{Gaya Kepemimpinan Idola FM}

Pembahasan gaya kepemimpinan dilakukan dengan menggunakan tema-tema tekstual temuan yang berasal dari analisis reduksi transendental fenomenologis hasil wawancara. Secara umum tema-tema tekstual yang berhasil ditemukan dalam penelitian ini dipilah berdasarkan pendekatan kepemimpinan yang dilakukan pemimpin redaksi Idola FM selaku informan, sebagai berikut: Informan berkedudukan sebagai Pemimpin Redaksi Idola FM. Ia bisa mencapai pucuk pimpinan redaksi dikarenakan memiliki pengalaman di bidang jurnalistik sejak tahun 2007. Selain itu, pengalamannya juga terlihat pada rekam jejaknya di bidang jurnalistik dan juga aktivitasnya di AJI (Aliansi Jurnalistik Independen) sebagai sekertaris di Kota semarang. Kapasitas dan integritas informan kemudian menjadikannya Pimpinan Redaksi di Idola FM. Informan menerapkan manajemen kemitraan dan tanggung jawab. Informan tidak segan bersikap keras jika ada bawahan yang tidak patuh dan bersikap lembut jika memang memungkinkan. Informan menyatukan bawahan dengan cara mencari komitmen. Hal tersebut diwujudkan dengan selalu memberi pengertian kepada bawahan bahwa profesi jurnalis bukanlah main-main. Informan selalu menegaskan kepada bawahan, suatubangsa bisa maju dariperanan para jurnalisnya. Informan juga selalu mengingatkan bawahan mengenai visi besar perusahaan yang diharapkan bisa membangun komitmen.

Informan menerapkan sistem reward and punishment kepada bawahan. Melalui sistem tersebut, diharapkan terdapat peningkatan profesionalisme para pekerja redaksi di Idola FM. Profesionalisme juga dilakukan dengan pembagian kerja secara terorganisir, melalui alur sebagai berikut: dari Redaktur in chief mengorganisir Koordinator Liputan untuk memantau pertimbangan isu untuk diberitakan, kemudian ditindak lanjuti dan menugaskan reporter untuk liputan ke lapangan.

Sebagai pemimpin redaksi, informan menjaga agar berita memiliki etika sehingga tidak merusak psikologi pendengar. Misalnya saja, agar tidak merusak psikologis pendengar, informan memilih tidak menayangkan peristiwa pembunuhan. Berita-berita yang dihadirkan di Idola FM diutamakan untuk menawarkan solusi, misalnya solusi agar kecelakaan kereta api tidak lagi terjadi. Dalam memberitakan korupsi misalnya, menerapkan prinsip asas praduga tak bersalah dari berjalannya sidang dan hasil putusan Komisi Pemberantasan Korupsi (KPK). Dari paparan dia atas, bisa diketahui bahwa gaya kepemimpinan yang diterapkan Idola FM adalah gaya kepemimpinan mendorong semangat komunitas. Gaya kepemimpinan mendorong semangat komunitas adalah pemimpin mengakui kontribusi para anggotanya melalui penghargaan atas prestasi yang sudah tercapai, sebagaimana dinyatakan Herrick (2003: 107-121).

Pemimpin redaksi Idola FM menerapkan gaya kepemimpinan mendorong semangat komunitas dikarenakan menganggap bawahan (karyawan) sebagai aset perusahaan. Karyawan adalah salah satu bentuk aset internal yang paling berharga yang dimiliki perusahaan. Dengan demikian, kebijakan dan usaha kuat untuk selalu menjaga dan mempertahankan karyawan diharapkan akan mampu menghindari berbagai hal yang mengakibatkan tidak tercapainya tujuan organisasi. Gaya kepemimpinan yang mendorong semangat komunitas ini bisa digolongkan ke dalam tipe pemimpin demokratis yang berorientasi pada manusia dan memberikan bimbingan kepada pengikutnya (Alma, 2008: 169-170). Seorang pemimpin yang menganut dan menggunakan gaya kepemimpinan demokratis, ada kalanya harus bertindak otoriter apabila (Siagian dalam Alma, 2008: 18): (1) Organisasi berhadapan dengan situasi gawat; (2) Organisasi menghadapi 
ancaman terhadap eksistensinya; (3) Para bawahan menunjukkan perilaku yang cenderung menjurus kepada bentuk-bentuk yang negatifatau bahkan destruktif; (4) Merosotnya disiplin kerja. Dengan demikian, jelas terlihat bahwa seorang pemimpin memiliki pengaruh besar dalam eksistensi perusahaan media massa karena mendorong peningkatan kinerja para karyawan guna tercapainya tujuan. Dengan demikian, pemimpin masa kini dituntut mampu memahami faktor kultural, bahasa, dan hukum negara dimana perusahaan beroperasi. Sebagaimana dinyatakan Gibson, Ivancevich dan Donnely, bahwa seorang pemimpin dalam manajemen media hasruslah mencari pengalaman, fleksibilitas, penyesuaian dan menghargai kultur orang lain. Pemimpin tidak boleh memiliki pandangan etnosentrik sempit (1996: 65).

\section{Simpulan}

Eksistensi sebuah perusahaan media lokal tidak cukup hanya mengedepankan lokalitasnya saja agar tidak ditinggal pasar. Suatu perusahaan media lokal juga harus memanfaatkan teknologi internet guna memperluas sebarannya sehingga bisa diakses oleh lebih banyak orang kapan pun dan dimana pun, sebagaimana yang dilakukan Idola FM. Eksistensi Idola FM semakin diperluas sebarannya karena menerapkan konvergensi media, salah satunya melalui radioidola.com.

Eksistensi sebuah perusahaan media tentu saja harus didukung dengan gaya kepemimpinan yang relevan dan bisa membawa perusahaan mencapai visi dan misi yang ditargetkan. Gaya kepemimpinan yang dianut Pemimpin Redaksi Idola FM adalah mendorong semangat komunitas. Artinya, pemimpin mengakui kontribusi para anggotanya melalui penghargaan (reward) atas prestasi yang sudah tercapai. Gaya kepemimpinan tersebut terbukti mampu menjadikan Idola FM eksis hingga sekarang.

Selain memiliki implikasi praktis, penelitian ini juga memiliki implikasi teoritis. Implikasi praktis penelitian ini berupa penerapan gaya kepemimpinan perusahaan media massa yang bisa membuat perusahaan media eksis dan berkembang. Implikasi teoritis penelitian ini bahwa falsafah "bad news is good news" ternyata tidak relevan lagi diterapkan saat ini. Falsafah lama tersebut tergantikan oleh falsafah baru "bad news is not a good news." Falsafah baru tersebut lebih efektif dan relevan diterapkan bagi kemajuan jurnalisme perusahaan media massa.

\section{Daftar Pustaka}

Ahmad, Nur. (2015). Radio Sebagai Sarana Media Massa Elektronik. ATTABSYIR: Jurnal Komunikasi Penyiaran Islam: Vol. 3, No. 2 Desember. Alma, Buchari. (2009). Pengantar Bisnis. Bandung: Alfabeta.

Atika, Djuara P. Lubis, Parlaungan Adil Rangkuti. (2017). Tingkat Pemenuhan Informasi Petani Melalui Radio Komunitas. Jurnal Komunikasi ASPIKOM, Volume 3 Nomor 3, Juli 2017, hlm 435 - 446. Azizi Aydin, Ali Vatankhah Barenj, Majid Hashmipour. (2016). Optimizing Radio Frequency Identification Network Planning Through Ring Probabilistic

Logic Neurons. Jurnal Advances in Mechanical Engineering Vol. 8(8) 112. DOI: $10.1177 / 1687814016663476$. a i m e.s a g e p u b. c o m. Brantas. (2009). Dasar-dasar Manajemen. Bandung: Alfabeta. Baran, Stanley J. Dan Dennis K. Davis. (2014). Teori Dasar, Komunikasi Pergolakan dan Masa Depan Massa, Edisi 5. Jakarta: Salemba Humanika.

Deuze, M. (2001). Online Journalism: Modelling the First Generation of News Media on the World Wide Web. Jurnal First Monday, Volume 6, Number 10, 1 October 2001. Fahmi,Irham. (2014).Perilaku Organisasi: Teori, Aplikasi, dam Kasus. Bandung: Alfabeta.

Griffin, Ricky W. (2013). Manajemen. Jakarta: Erlangga.

Denzin K. Norman dan Yvonna S. Lincoln. 2011. Handbook of Qualitative Research, 4th Edition. USA: SAGE Publications, Inc. 
Herrick, Dennis F. (2003). Media Management in The Age of Giants: Bussiness Dynamic of Journalism. Iowa: Iowa State Press-Blacwell. Keith, MichaelC.(2000). Stasiun Radio Teknologi (Terj.). Jakarta: Internews Indonesia. Darmanto, dkk. (2009). Pengelolaan Radio Komunitas. Combine Resource Institution.

Geller, Valerie. (2007). Creating Powerful Radio. USA: Focal Press Publications.

Gibson, James L, John M. Ivanevich, James H. Donnely, Jr. (1996). Organisasi: Perilaku, Struktur, Proses. Edisi 8 Jilid 1. (terj.). Jakarta: Binarupa Aksara. Goggin, Gerard. (2006). Cell Phone Culture, Mobile Technology in Everyday Life. London: Routledge. Jing Wang and Miodrag Bolic. (2017). Indoor Localization Using Augmented

Ultra-high-frequency Radio Frequency Identification System for Internet of Things. International Journal of Distributed Sensor Networks Vol.

13(11). DOI: $10.1177 / 1550147717739814$. journals.sagepub.com/home/ijdsn. Littlejohn, Stephen W, Karen A. Foss. (2008). Theories of Human Communication, 9th edition. USA: Thompson Wadsworth.

Liliweri, Alo. (2011). Komunikasi Serba Ada Serba Makna. Jakarta: Kencana Prenada Media Group. Moustakas, Clark. (1994). Phenomenological Research Methods. Thousands Oaks: Sage Publications.

Nightingale, Virginia. (2011). 'The Handbook of Media Audiences'. Dalam Green Joshua dan Henry Jenkins (eds). Spreadable Media: How Audiences Create Value and Meaning in a Networked Economy. UK: Blackwell Publishing.

Noor, Henry Faizal. (2015). Ekonomi Media. Jakarta: Mitra Wacana Media.

Pratiwi, Nugrahaning Esa, Richard Gordon Mayopu, George Nicholas Huwae.
(2015). Aktivitas Media Relations Humas Setda Kota Salatiga Dalam membentuk Berita Positif. Jurnal Komunikasi ASPIKOM, Volume 2 Nomor 5, Juli 2015, hlm. 330-345. Pavlik, J. (2001). Journalism and New Media. New York: Columbia University Press.

Quinn, Stephen dan Stephen Lamble. (2014). Online News Gathering: Research and Reporting for Journalism. Amsterdam; Focal press.

Sobur, Alex. (2013). Filsafat Komunikasi: Tradisi dan metode Fenomenologi. Bandung: PT Remaja Rosdakarya.

Stephen P. Robbins. (1990). Teori Organisasi: Struktur, Desain, dan Aplikasi (terj.). Jakarta: Arcana. Widiana, Ida Bagus, A.A. Gede Agung, I Kadek Suartama. (2015). Pengembangan Program Siaran Radio Melalui Acara Kreativitas Sastra Programa 2 RRI Singaraja Pada Siswa Pengambil Ektrakulikuler Jurnalistik di SMP Negeri 2 Singaraja Tahun Ajaran 2014/2015. e-Journal Edutech Universitas Pendidikan Ganesha Jurusan Teknologi Pendidikan Vol. 3 No: 1. 